\title{
Insegnare il disegno di architettura tra pandemia e semestralizzazione
}

\author{
Laura Carnevali \\ Fabio Colonnese
}

Abstract

Questo contributo descrive e analizza gli esiti dell'ultimo corso di Disegno dell'Architettura con Laboratorio al primo anno del Corso di Laurea Magistrale a ciclo unico in Ingegneria Edile-Architettura della Facoltà di Ingegneria civile e ambientale dell'Università Sapienza di Roma. II corso è stato riorganizzato per rispondere sia alla sua semestralizzazione, sia alle misure messe in atto per contrastare la diffusione della pandemia da COVID-19. In questo senso, il corso di quest'anno è stato concepito come una opportunità per sperimentare metodi e argomenti con grande flessibilità e per riflettere retrospettivamente sull'insegnamento stesso. I primi esiti prodotti dagli studenti consentono di esplorare i limiti dell'insegnamento del disegno a distanza e in modalità mista, di riflettere sulle attuali condizioni dei docenti, di descrivere le reazioni degli studenti e le soluzioni che potrebbero avere un futuro.

Parole chiave

disegno di architettura, insegnare il disegno, COVID- 19, Frank O. Gehry, Danziger House.

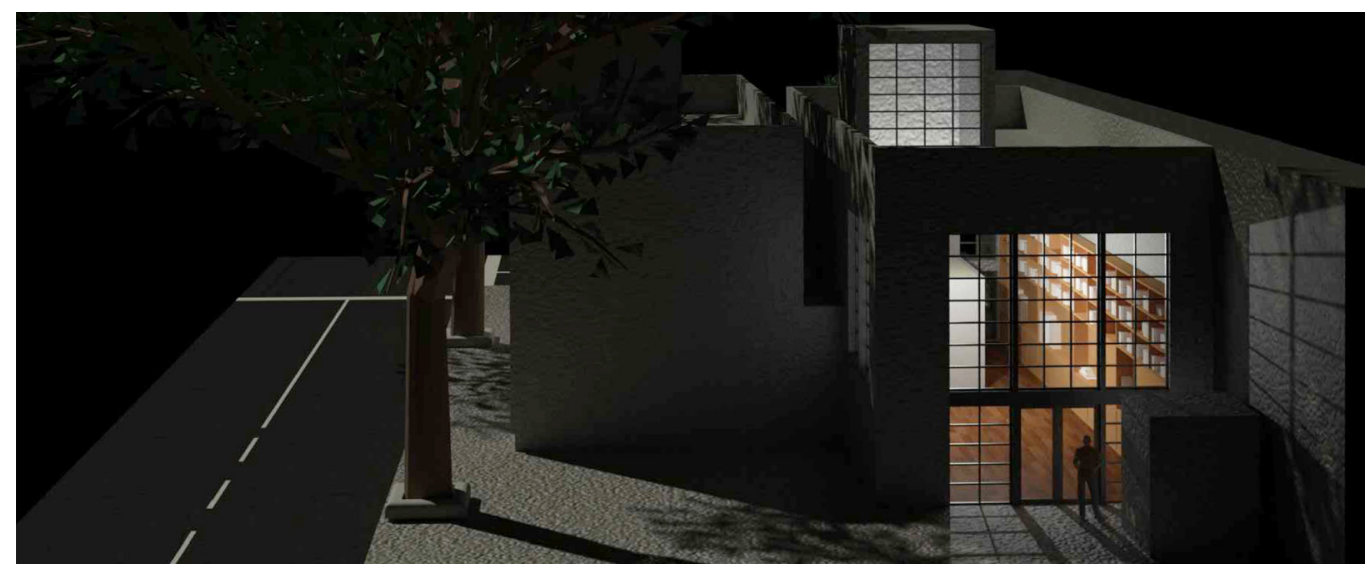




\section{Organizzazione del corso}

Nel contesto del corso di laurea in Ingegneria Edile-Architettura, il corso di Disegno dell'Architettura I con Laboratorio si propone l'obiettivo specifico di fornire agli allievi 'ingegnere/ architetto' i metodi e gli strumenti mentali, grafici e informatici che consentono di 'vedere, leggere e disegnare' lo spazio architettonico. In particolare, si stimola l'intuizione geometrica, fornendo adeguati strumenti sia per rappresentare le configurazioni spaziali che per risolvere i problemi geometrici e relazionali, nel quadro di un complessivo obiettivo progettuale. II corso si compone complessivamente di 162 ore (I2 CFU) suddivise in 5 I ore di lezioni frontali, 5 I ore di esercitazioni e 60 ore di Laboratorio. Sin dalla sua istituzione e fino all'A.A. $2019 / 2020$, il corso è stato suddiviso in due o addirittura tre canali. Ha sempre avuto un carattere estensivo, con inizio delle lezioni a fine ottobre e termine a fine maggio. Nel 2020/202 I, a causa della lenta ma progressiva contrazione numerica degli iscritti alla classe di laurea LM4, è stato mantenuto un solo canale di Disegno dell'Architettura I e il corso di Laurea è diventato un corso intensivo. Di conseguenza, anche il corso di Disegno è stato compresso in forma semestrale, mantenendo ovviamente inalterate le ore e i CFU complessivi. Poco prima dell'inizio del corso, la titolare ha conseguito dagli uffici competenti una idoneità con prescrizione di limitazione di attività in presenza in emergenza sanitaria COVID 19. Pertanto, il corso è stato tenuto inizialmente a distanza dal titolare con la presenza in aula di uno studioso e dottore di ricerca. Questa situazione si è protratta sino all'assegnazione del corso, tramite bando, al docente a contratto, che ha proseguito in presenza, così come stabilito da Sapienza per i soli corsi del primo anno. Questa dinamica ha portato a una naturale e fattiva collaborazione tra i due docenti.

La semestralizzazione del corso ha invece portato a una naturale rivisitazione del programma consolidatosi e aggiornatosi negli anni soprattutto per merito del lavoro del compianto Cesare Cundari. Pur mantenendo la tradizionale suddivisione in lezioni, esercitazioni (esercizi di geometria descrittiva, di percezione visiva e di rappresentazione dell'architettura sia in ambito analogico che digitale) e attività di Laboratorio, si è deciso di ridurre il numero delle tavole e di lasciare alcuni argomenti come facoltativi (fig. I). A queste difficoltà, e a tutte quelle di ordine tecnico e strumentale, si è anche aggiunta quella dovuta a un problema relativo ai subentri legati ai test di ammissione che ha comportato l'iscrizione tardiva di circa un quarto degli studenti che si sono aggiunti quando le lezioni erano iniziate più di un mese prima.

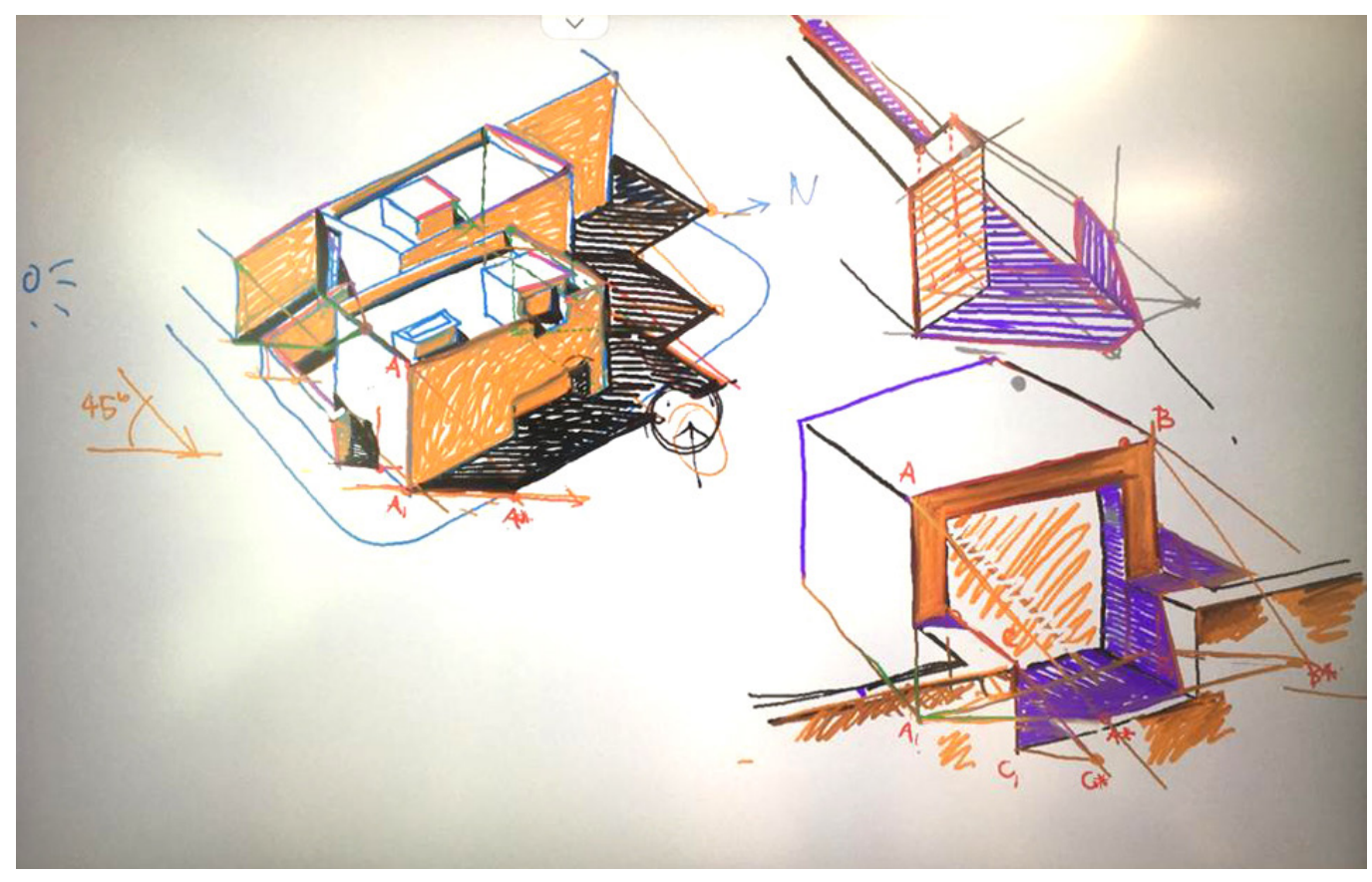




\section{II laboratorio progettuale}

Il laboratorio costituisce tradizionalmente il cuore del corso, nel quale gli studenti sono chiamati ad applicare le nozioni di geometria alla rappresentazione di un edificio di un autore significativo scelto nella produzione moderna e contemporanea. Si tratta, in questo caso, della Danziger House che l'architetto americano Frank O. Gehry ha progettato e costruito a Los Angeles tra il 1963 e 1965 (fig. 2). Autore e opera sono stati scelti con motivazioni diverse e, per certi versi, complementari. Frank O. Gehry, superati i novanta anni, appare oggi come uno dei maestri indiscussi dell'architettura contemporanea. È stato capace di interpretare in modo originale il contributo dei maestri del razionalismo europeo migrati in California, come Richard Neutra e Rudolf Schindler, attraverso le espressioni di artisti contemporanei che spaziano dalla Pop Art alla Land Art, una inedita sensibilità al paesaggio urbano e il recupero dei materiali industriali. Per trasferire il suo approccio scultoreo all'architettura, ha sviluppato una originale procedura, poi definita come reverse modeling, che ha coinvolto strumenti usati, fino a quel momento, solo nell'aeronautica militare d'avanguardia, per misurare le sollecitazioni strutturali delle carlinghe. L'applicazione di scansioni laser e modellazione digitale gli ha concesso di trasferire le superfici dei suoi piccoli modelli in carta, tessuto e rete prima nell'ambiente vettoriale del CAD, per essere rielaborati e ottimizzati, e poi nella struttura stessa degli edifici. Proprio un tale approccio al processo di elaborazione formale dell'architettura ha costituito un'occasione per affrontare, in chiave didattica, l'evoluzione del processo progettuale e le numerose relazioni che esso instaura in chiave analogica e digitale con la realtà da trasformare. In questo senso, gli studenti sono stati chiamati a scegliere un'opera di Gehry e a preparare una breve relazione da presentare ai loro colleghi mediante il supporto di due o tre diapositive di immagini, una delle quali di disegni. Nel vastissimo panorama della produzione di Gehry, la Danziger House è stata scelta per la sua apparente semplicità (fig. 3). Progettata nell'arco di due anni, al ritorno da un lungo viaggio in Europa, la casa esprime la negoziazione formale tra alcune esperienze europee e la tradizione californiana. La casa è esposta su tre lati un lotto di testata di una lunga schiera di edifici. È composta da due grandi volumi parallelepipedi slittati e accostati, che contengono rispettivamente la zona residenziale e la zona produttiva richiesta dal cliente, un artista

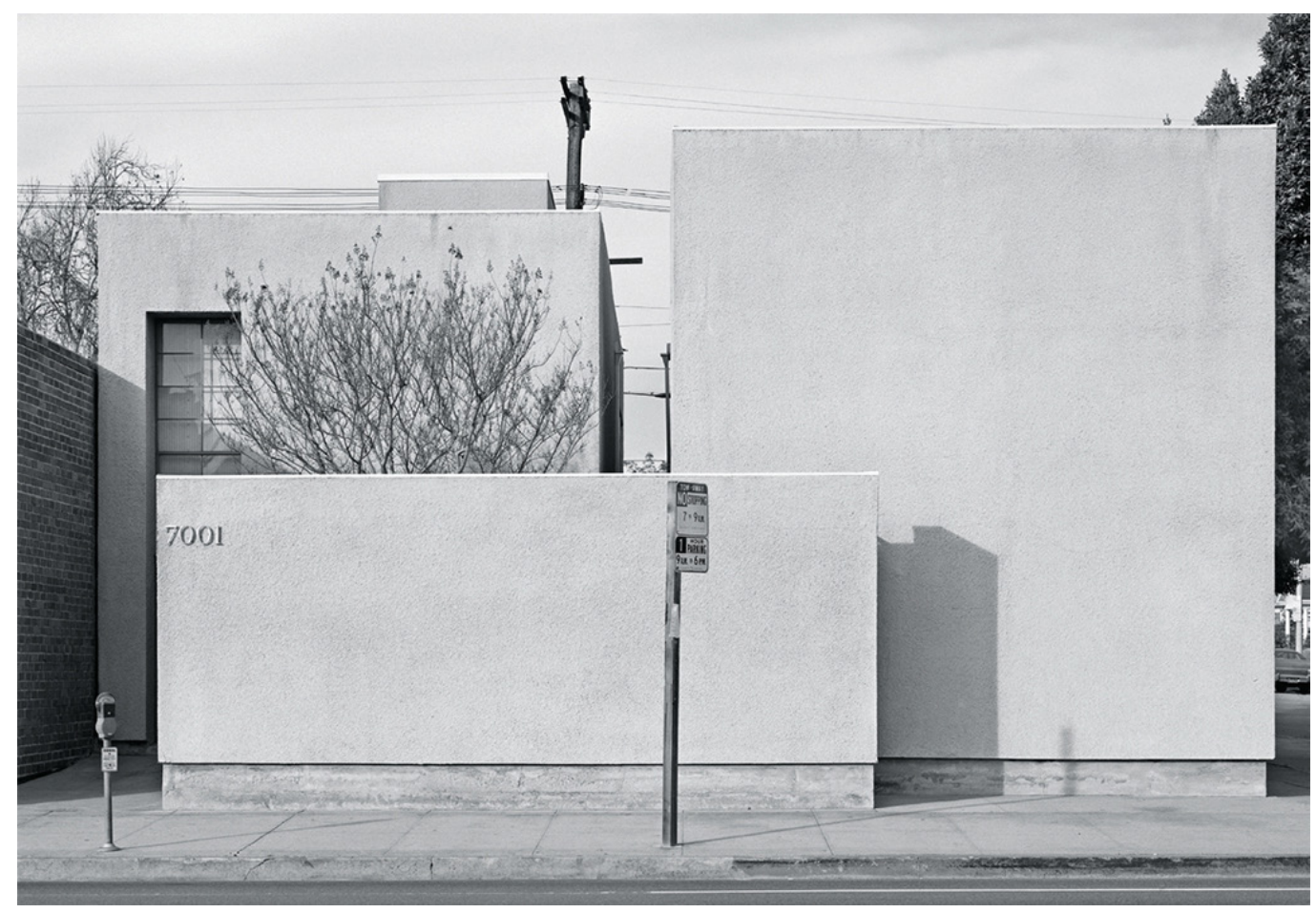


fotografo, al di sopra dei quali torreggiano due lucernari cubici. Mentre lo studio presenta un ingresso indipendente, il volume residenziale appare completamento chiuso all'esterno, se si esclude la porta del garage (fig. 4). L'ingresso avviene quindi in maniera informale attraverso il cancello che conduce al giardino, protetto dalla strada principale, Melrose Avenue, da un alto muro di cinta che gira a gomito. Da qui, attraverso una grande vetrata, si accede al volume residenziale, caratterizzato da un soggiorno a doppia altezza. Al di sopra della cucina si affaccia la camera degli ospiti, mentre la camera padronale è separata dalle scale poste trasversalmente. Una porta conduce dalla cucina allo studio, anch'esso a tutt'altezza, che contiene il volume basso dedicato alla camera oscura e si apre con vetrate a nord e a est. La documentazione grafica e iconografica sulla casa [Cohen 20 I8], limitata anche per l'impossibilità di accedere alle biblioteche, è stata arricchita dalla esplorazione del sito tramite Google-Maps e Google-Streetview. Rispetto al progetto originario, i successivi proprietari hanno modificato sia l'esterno che l'interno della casa. Gli studenti sono stati perciò chiamati a ripristinarne, nei loro disegni, lo stato originale.

In primo luogo, gli studenti hanno dovuto applicare i contenuti teorici della Geometria Descrittiva acquisiti durante le lezioni allo scopo di realizzare una pianta e un prospetto con le ombre (fig. 5), una prospettiva col procedimento del ribaltamento (fig. 6), una assonometria d'esterno con le ombre, uno spaccato oppure un esploso assonometrico (fig. 7). L'ultima tavola di disegno manuale è dedicata allo studio di un percorso di avvicinamento e di esplorazione della casa dall'esterno all'interno attraverso una serie di schizzi prospettici (fig. 8), a volte a colori. In questo senso, i volumi esterni della casa, rigorosamente 'cartesiani', e gli interni con le doppie altezze offrono un campionario di forme che consente agli studenti una transizione 'dolce' e 'mediata' dai solidi platonici delle esercitazioni di geometria al disegno di architettura in scala.

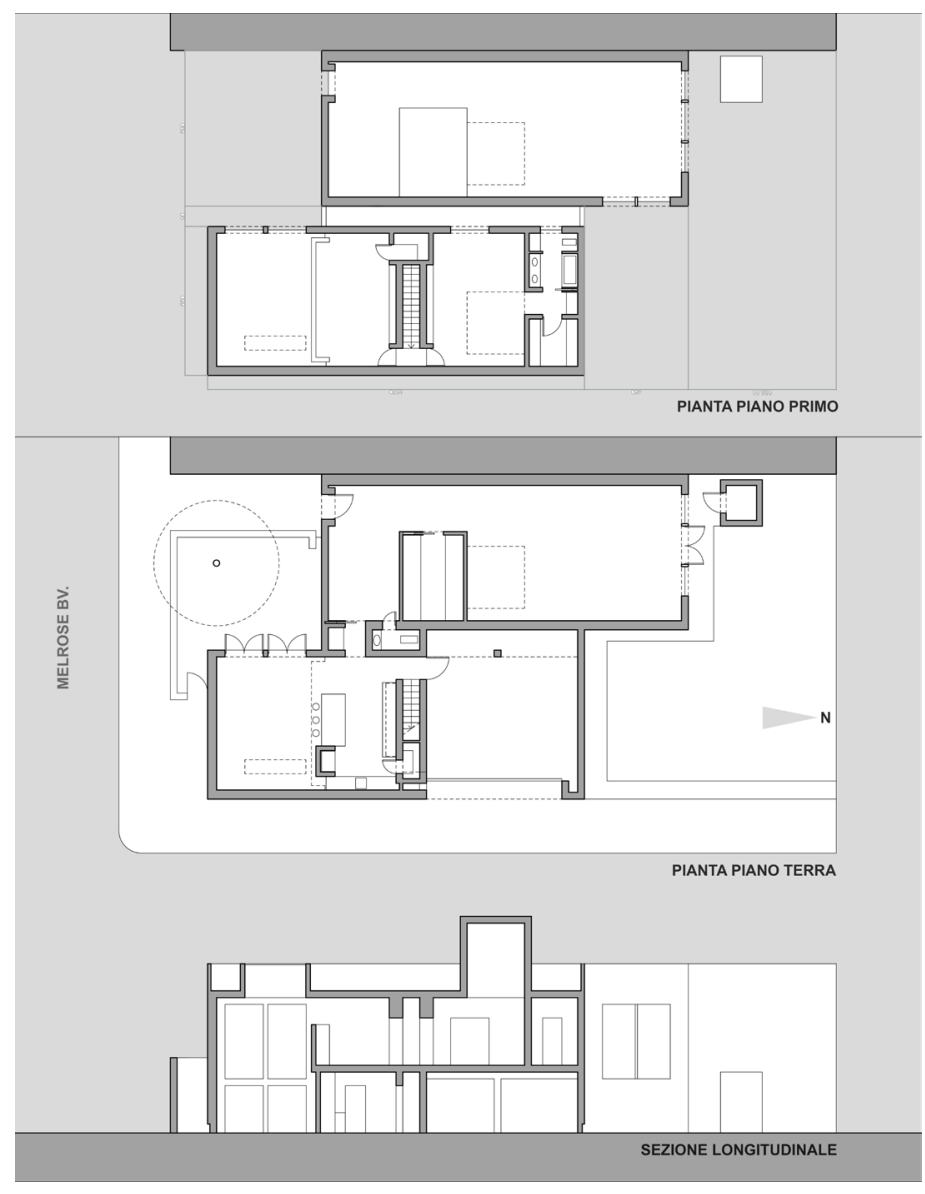




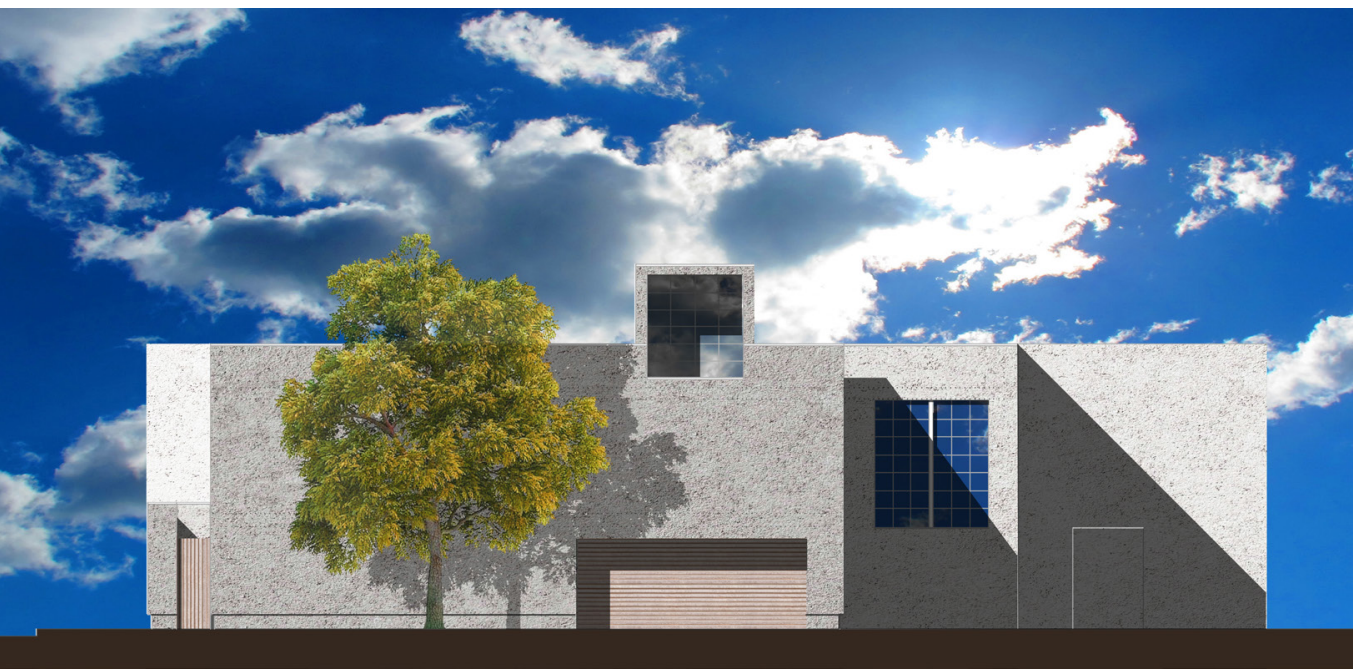

A queste si aggiungono due tavole in formato digitale. Nella prima, lo studente è chiamato ad assemblare le proiezioni ortogonali della casa, in parte fornite dal corso, in parte elaborate dallo studente stesso, aggiungendo scala grafica, testi, linee di sezione e altri segni convenzionali. La seconda tavola è invece dedicata alle viste dal modello solido digitale costruito collegialmente durante le attività di laboratorio rappresentato con modalità che vanno dal wireframe al rendering con materiali e ombre (figg. 9-I I).

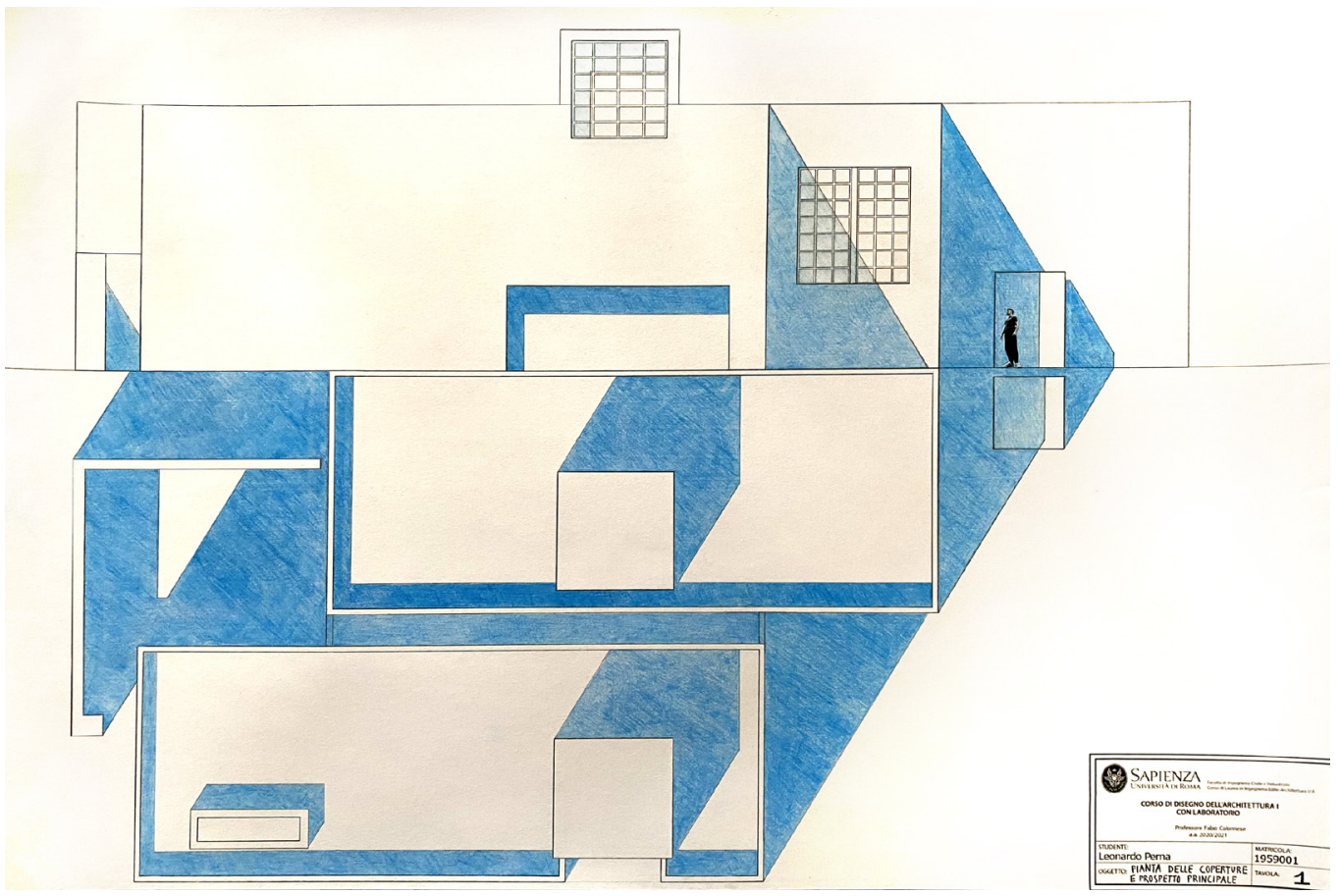

\section{Strategie e reazioni}

Quando l'insegnamento e le esercitazioni si svolgono normalmente in presenza, le matricole, dopo un primo periodo di orientamento, iniziano a relazionarsi tra di loro. Si organizzano tendenzialmente in piccoli gruppi e sviluppano il sostegno reciproco, lo scambio di informazioni utili, l'emulazione delle 'buone pratiche'. Questa maturazione delle cosiddette soft skills 
Fig. 6. F. Gehry, Danzige House, 1964-1965.

Prospettiva col metodo cel ribaltamento

(elaborazione grafica L.

Perna).

Fig. 7. F. Gehry, Danziger House, 1964-1965.

Spaccato assonometrico in scala 1:100 (elaborazione grafica A. Cricenti).

Fig. 8. F. Gehry, Danziger House, 1964-1965.

Schizzi lungo un percorso

(elaborazione grafica R.D. Carcione).
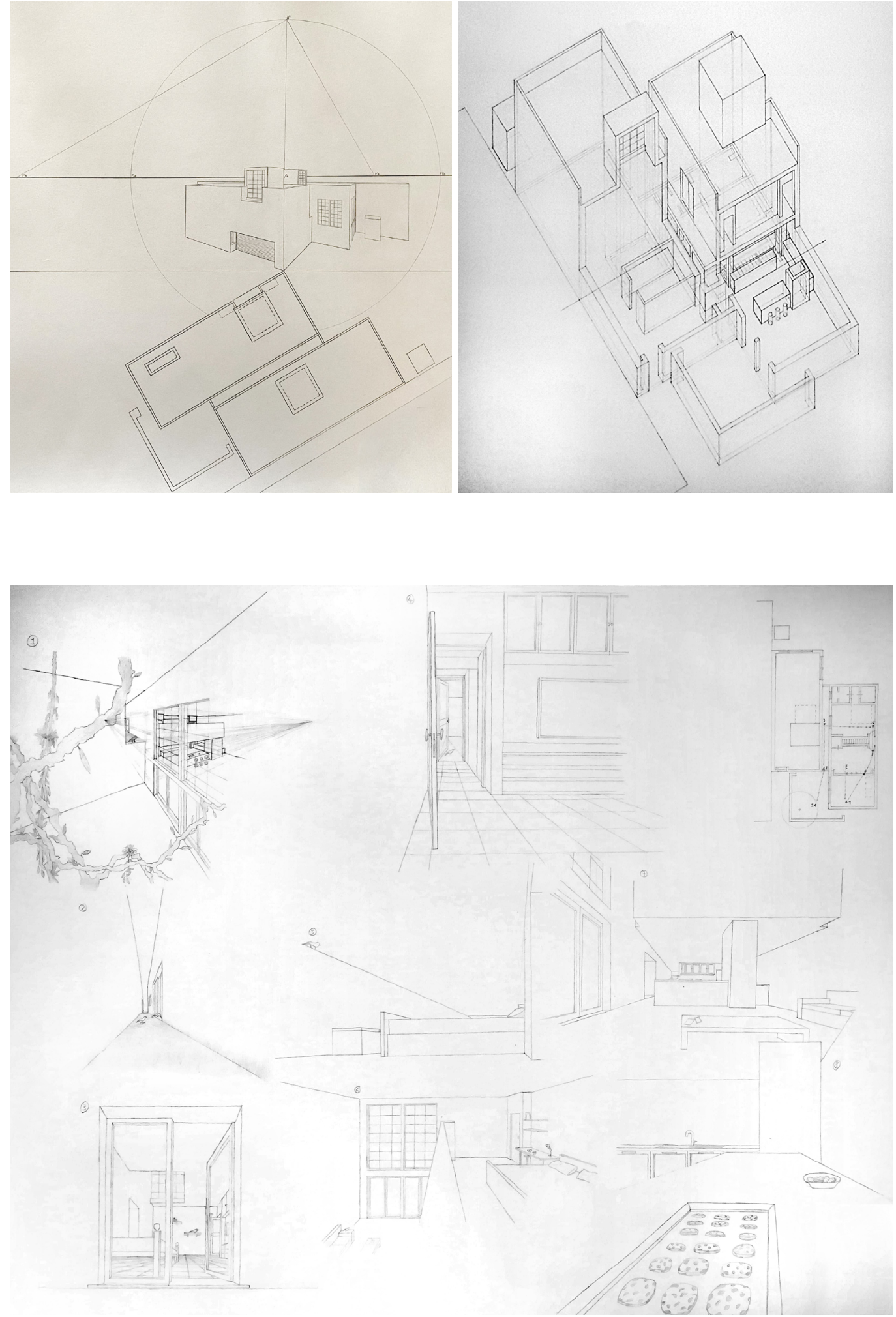
porta a una crescita di fiducia in sé e si affianca a una serie di comportamenti che in breve trasformano una serie di individui in una aula dotata di una sorta di intelligenza collettiva. L'insegnamento a distanza, al di là dell'alienazione del docente di fronte allo schermo, ha anche la controindicazione di disincentivare questi comportamenti e mantenere il rapporto tra docente e studente sul piano dell'individualità. Per ovviare a questa limitazione, oltre a piattaforme istituzionali come E-learning, si sono messi in campo alcuni espedienti utili a stimolare la condivisione e a favorire un ambiente di lavoro non competitivo ma anzi aperto all'errore e alla sperimentazione. La correzione collegiale, benché anonima, delle tavole di Geometria Descrittiva è uno di questi espedienti. Un altro è la già citata presentazione pubblica delle opere di Gehry. Nella tavola dedicata agli schizzi della casa, si è suggerito di pensare a percorsi e soggetti particolari, introducendo una componente narrativa da "gioco di ruolo" utile a coinvolgere l'immaginazione degli studenti.

In alcuni casi, si sono formati spontaneamente piccoli gruppi di studio che hanno lavorato nelle case pur mantenendo distanze e presidi medici. Ma si sono anche stimolati gli studenti a disegnare collegialmente pur restando nelle loro case mediante strumenti i che permettono di dialogare, condividere immagini e video, e di sentire musica assieme, per esempio con applicazioni come Discord. In questo senso, i docenti hanno promosso il corso come un ambiente di lavoro non-competitivo ma piuttosto aperto all'errore, alla sperimentazione e alla condivisione.

Un altro aspetto che è venuto a mancare è l'emulazione del docente, che non può più sedersi fianco a fianco agli studenti per disegnare insieme, sui loro stessi fogli. Per supplire a questo, si è cercato di utilizzare il meno possibile le tradizionali presentazioni con slides. Si è invece disegnato sempre dal vivo, sia nelle spiegazioni dei metodi di rappresentazione, sia nella esplorazione collegiale di Casa Danziger. Si è disegnato sia sulla tavoletta grafica con

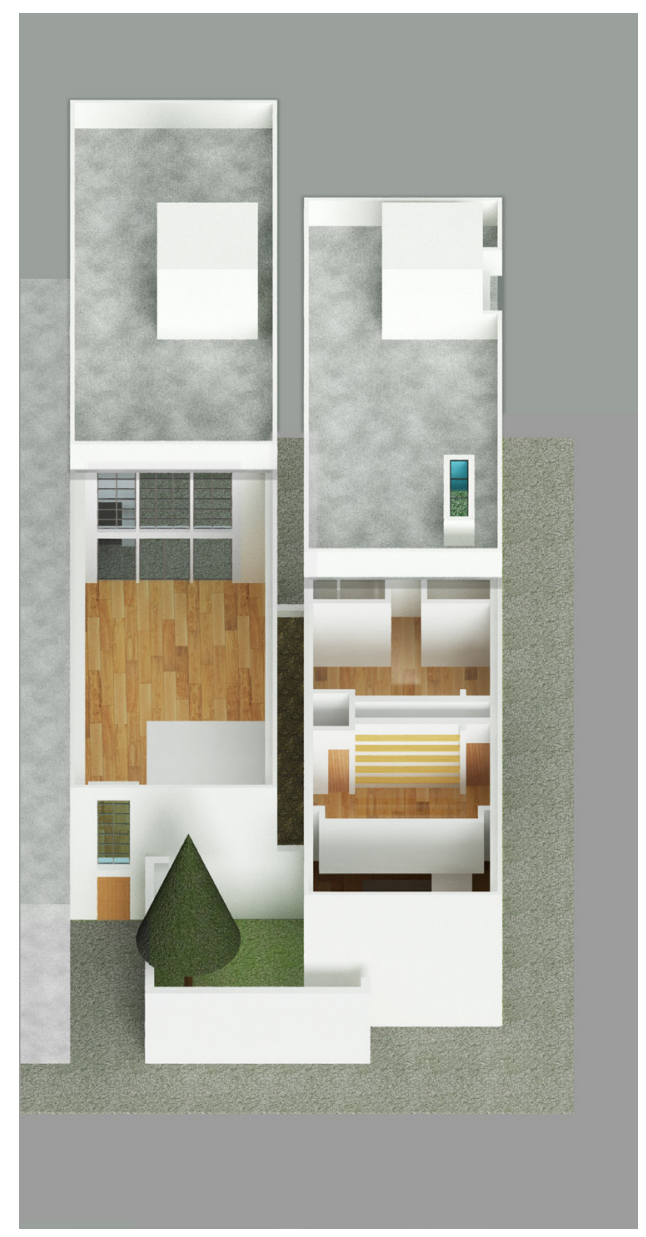




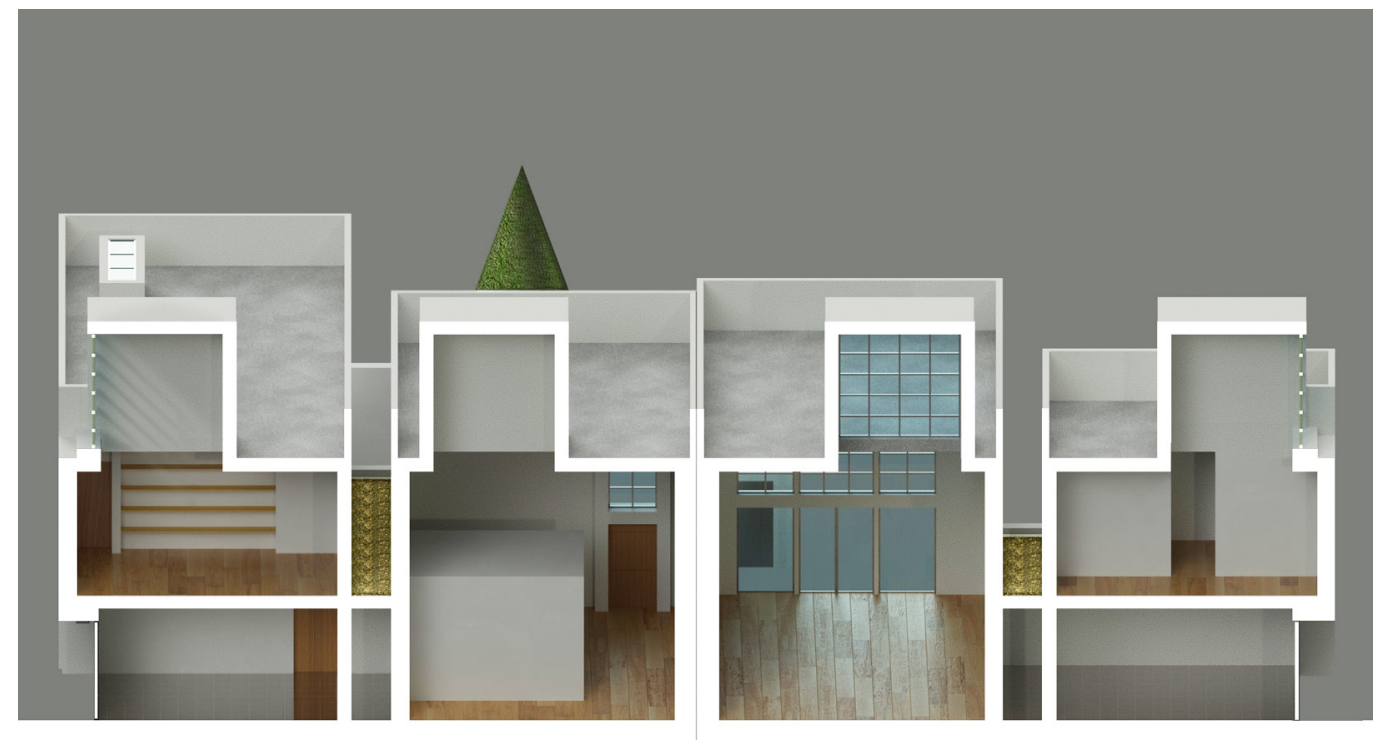

Adobe Photoshop e Apple Concept, sia sulla lavagna digitale di grande formato presente in aula, dotata di strumenti per la pittura digitale (fig. 12). Spesso anche le correzioni delle tavole sono avvenute con disegni digitali da screenshots delle tavole. Per facilitare questo processo, agli studenti è stato chiesto di disegnare con matite morbide, al posto delle tradizionali $2 \mathrm{H}$, per rendere i loro disegni più visibili, e gli sono state fornite nozioni di Photoshop per ottimizzare la scansione dei disegni stessi.

Gli studenti hanno apparentemente reagito con una presenza crescente al corso. Si è passati dalle sette presenze delle prime lezioni di ottobre alle 28 presenze, circa metà degli iscritti, alla fine di novembre. Nonostante i turni previsti, alcuni studenti hanno chiesto di poter essere presenti quasi a tutte le lezioni mentre altri hanno preferito restare costantemente a casa. Gli studenti sono stati accompagnati all'esame, attraverso alcune revisioni collegiali da remoto e tramite numerose mail di correzioni individuali. Nell'impossibilità di svolgere esami scritti da remoto in forma convenzionale, i contenuti di Geometria Descrittiva sono stati verificati mediante una serie di piccoli esercizi da svolgere di fronte al docente, mentre le tavole del laboratorio sono state presentate attraverso fotografie.

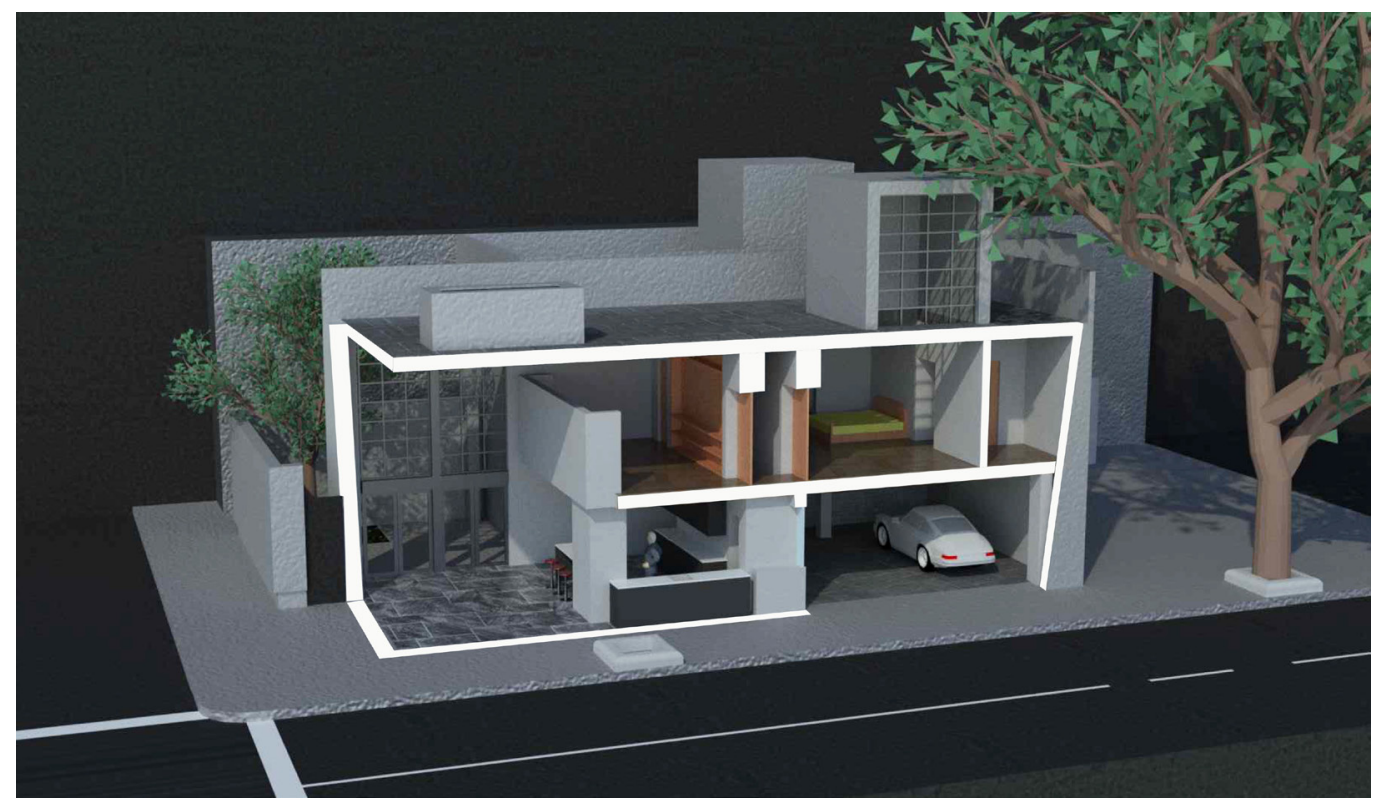




\section{Conclusioni}

I primi risultati della rivisitazione critica del programma e della sperimentazione di metodi e argomenti differenti dovute alla pandemia e alla semestralizzazione del corso di Disegno dell'Architettura si possono leggere negli esami degli studenti. Nel febbraio 202 I sono stati effettuati 54 esami di 67 studenti iscritti, circa l' $80 \%$ del totale. Questo risultato permette di formulare un primo giudizio circa l'efficacia e i limiti dell'insegnamento del disegno architettonico a distanza e, allo stesso tempo, sugli effetti della semestralizzazione della durata del corso. Mentre il numero di esami può essere considerato un buon risultato in termini quantitativi, la qualità generale del lavoro degli studenti mostra un evidente calo. Alcune tavole, in particolare le applicazioni della teoria delle ombre, dimostrano le difficoltà degli studenti di vedere con la mente in tre dimensioni. Questo sembra confermare che, nonostante il programma sia stato parzialmente ridimensionato, il tempo necessario agli studenti per assimilare concetti spaziali complessi non può essere compresso. Sviluppare la capacità di esplorare mentalmente problemi tridimensionali può richiedere mesi e molti esercizi e sembra essere incompatibile con un corso che inizia a ottobre e termina a gennaio. Allo stesso tempo, alcuni studenti hanno perso le ultime revisioni e l'opportunità di affinare e perfezionare i loro lavori. Questo primo giudizio deve essere ponderato anche con le condizioni particolari dell'insegnamento a distanza, naturalmente. Gli stessi studenti hanno sottolineato che, nonostante le difficoltà di accesso all'università, l'aula offre occasioni di concentrazione e di applicazione di gran lunga superiori a quelle che possono trovare a casa. Tuttavia, la crescente frequenza in aula costituisce solo in parte un indice di gradimento, poiché è stata condizionata da fattori esterni quali le modifiche alle restrizioni al movimento, l'aumento del numero di contagi e perfino l'assenza di altri docenti nel pomeriggio, che avrebbe costretto gli studenti a rientrare in casa in pochi minuti per assistere alla lezione on-line.

Un altro aspetto è quello squisitamente tecnico. L'implementazione della strumentazione hardware e software durante il corso ha costretto insegnanti e studenti a un costante aggiornamento. Le difficoltà tecniche legate all'efficienza di hardware e software sono state

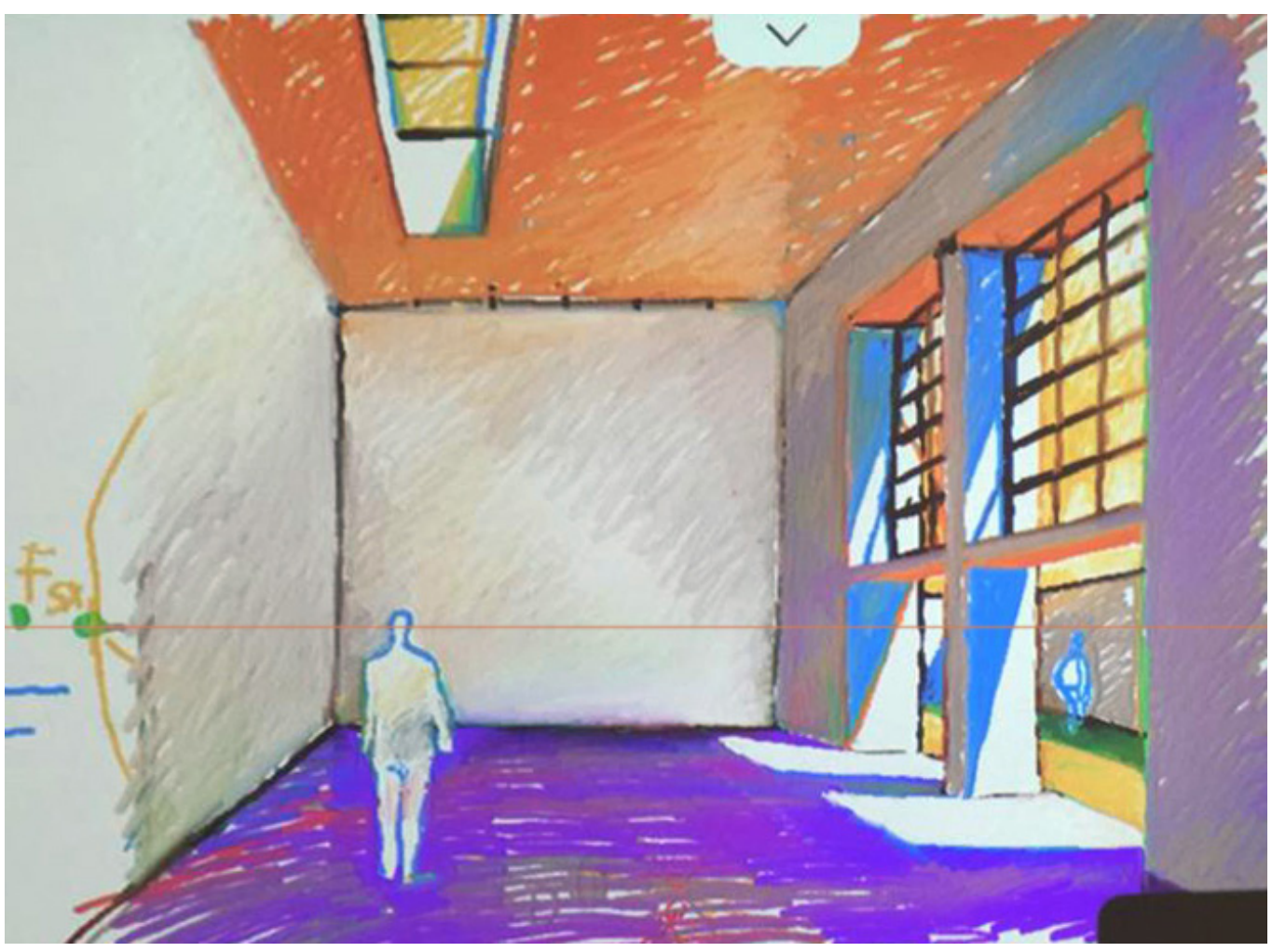


superate solo dal costante impegno e creatività dei docenti e dalla pazienza e partecipazione degli studenti. Questo aspetto porta alla considerazione che, in molti casi, le condizioni imposte dalla pandemia sembrano aver favorito una situazione favorevole. Tutte queste dinamiche, e la generale situazione 'ostile' allo svolgimento di una tradizionale lezione di disegno, ha favorito un clima eccezionale di partecipazione, interazione e solidarietà tra docenti e studenti, 'tutti sulla stessa barca' sulle quali sarebbe importante continuare a riflettere e sperimentare anche nell'immediato futuro.

\section{Ringraziamenti}

Si ringraziano gli studenti del corso, e in particolare Renato Danilo Carcione, Alessandra Cricenti e Leonardo Perna, per la loro attiva partecipazione.

\section{Riferimenti bibliografici}

Cohen J.L. (20 I 8). Danziger Studio and Residence, Los Angeles, 1964- 1965. In Domus, n. 1020, pp. 20-30.

\section{Autori}

Laura Carnevali, Sapienza Università di Roma, laura.carnevali@uniromal.it

Fabio Colonnese, Sapienza Università di Roma, fabio.colonnese@uniromal.it

Per citare questo capitolo: Carnevali Laura, Colonnese Fabio (202I). Insegnare il disegno di architettura tra pandemia e semestralizzazione/ Teaching architecture drawing between pandemic and semi-annualization. In Arena A., Arena M., Mediati D., Raffa P. (a cura di). Connettere. Un disegno per annodare e tessere. Linguaggi Distanze Tecnologie.Atti del $42^{\circ}$ Convegno Internazionale dei Docenti delle Discipline della Rappresentazionel Connecting. Drawing for weaving relationship. Languages Distances Technologies. Proceedings of the $42^{\text {th }}$ International Conference of Representation Disciplines Teachers. Milano: FrancoAngeli, pp. 145 | - 1470. 


\title{
Teaching Architecture Drawing between Pandemic and Semi-Annualization
}

\author{
Laura Carnevali \\ Fabio Colonnese
}

Abstract

This contribution describes and analyses the results of the Architecture Drawing course with Laboratory (2020/2 I) at the first year of the Master's Degree Course in Building Engineering-Architecture, Faculty of Civil and Environmental Engineering, Sapienza University, Rome. The course was reorganized to respond to both its conversion into a six-month one and the measures arranged to slow the spread of the COVID-19 pandemic. In this sense, the course was conceived as an opportunity to experiment methods and procedures with great flexibility and to reflect retrospectively on teaching practice. The early results produced by the students allow to explore the limits and potential of both remote and mixed-mode teaching of architectural drawing, to evaluate the limits of an architectural drawing course compressed in a six-month format, to reflect on teachers' conditions, to discuss the students' reactions and occasional solutions that could be effective in future.

Keywords

architecture drawing, drawing teaching, COVID-19, Frank O. Gehry, Danziger House.

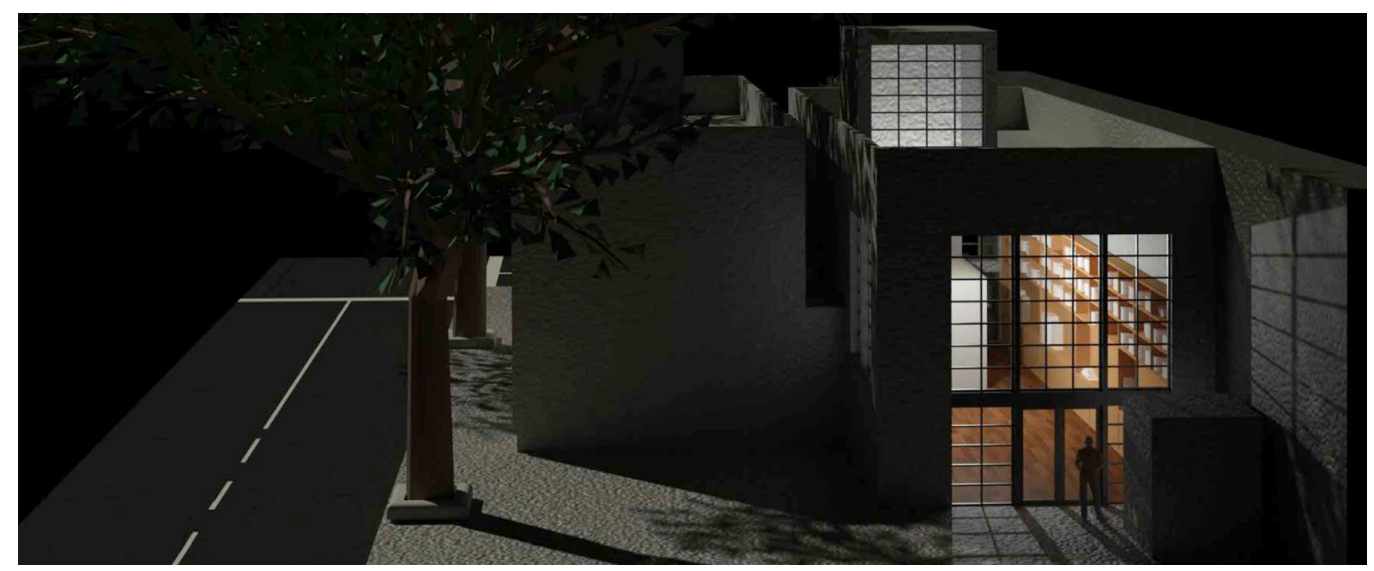




\section{Course organization}

The first year Architecture Drawing course aims at providing the registered engineer/ architect students with the mental, graphic and computer methods and tools that allow them to see, read and draw the architectural space. In particular, their geometric intuition is stimulated both to represent spatial configurations and to solve geometric and relational problems, within the framework of an overall design objective. The course comprises a total of 162 hours ( 12 Formative Credits or CFU) divided into 5 I hours of lectures, 5 I hours of exercises and 60 hours of laboratory. Since its inception and up to the academic year 2019/2020, the course has been divided into two or even three parallel channels. The lessons began at the end of October and ended by the end of May. In recent years, Sapienza University has suffered from a general decline in the number of students. In addition to this, both the students' representatives and some teachers have requested a revision of the organization of the courses, Architecture Drawing resulting compressed in a semester format. Moreover, only one channel has been activated, obviously keeping the total hours and credits unchanged. The Sapienza sanitarian offices declared that Laura Carnevali, the institutional course holder, was only suitable for distance teaching in the presence of a COVID 19 health emergency. Therefore, the course was initially held at a distance from the holder, until the assignment to an external teacher, Fabio Colonnese, who continued in attendance, as established by Sapienza. This dynamic led to a natural and effective collaboration between the two teachers. The new six-months format of the course led to a review of the program, which had consolidated and updated over the years also thanks to the work of the late Cesare Cundari. While maintaining the traditional division into lessons, exercises (in Descriptive Geometry, visual perception and analogic and digital architectural representation) and laboratory activities, the teachers decided to reduce the number of exercises and to leave some parts as optional (fig. I). Besides the many technical and instrumental difficulties, the late registration of about a quarter of the students after the admission tests caused some of them to join the class more than a month after the first lesson.

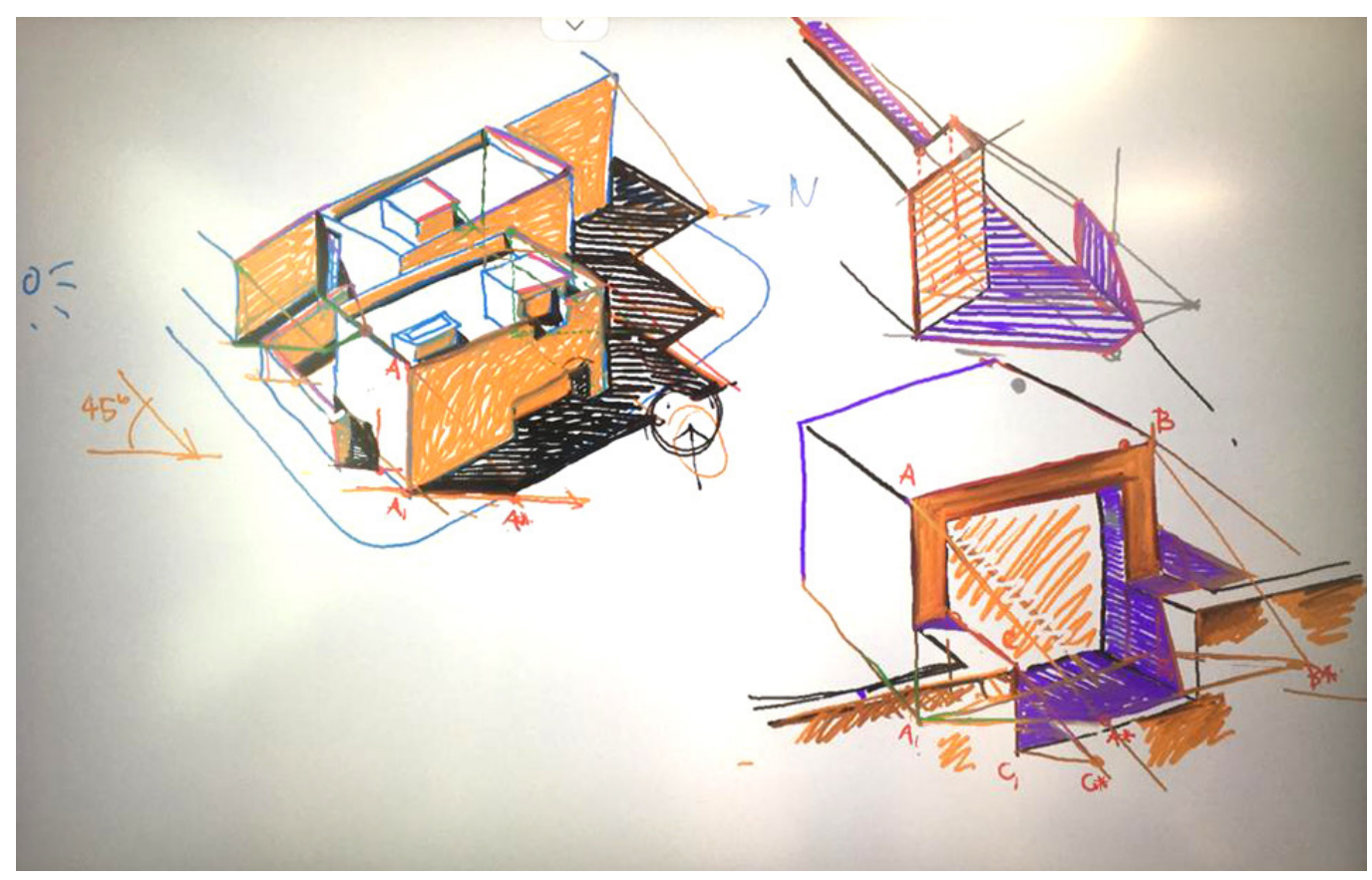




\section{Design Laboratory}

The Laboratory is the core of the course. Here the students are usually asked to apply the geometric and perceptive notions to the representation of a building by a significant author chosen in modern and contemporary scenario. This is the case of the Danziger House, designed and built by the Canadian American architect Frank O. Gehry in Los Angeles between 1963 and 1965 (fig. 2). The author and work were chosen for different and, in some ways, complementary reasons. At the age of ninety, Frank O. Gehry is considered today one of the undisputed masters of contemporary architecture. He was able to interpret in an original way the contribution of the masters of European rationalism who migrated to California, such as Richard Neutra and Rudolf Schindler, through the expressions of contemporary artists ranging from Pop Art to Land Art and an unprecedented sensitivity to the urban landscape and industrial materials. To transfer his sculptural approach to architecture, he developed an original procedure, later defined as 'reverse modeling', which involved tools borrowed from aircraft engineering, to measure the structural stresses of the cockpits. The application of laser scans and digital modelling allowed him to transfer the surfaces of his small models in paper, fabric and mesh first in the vector space of CAD, to be reworked and optimized, and then into the structure of the buildings. Such a revolutionary approach to the formal development of architecture provided an opportunity to address, from an educational point of view, the evolution of the design process and the relationships that it establishes with the reality in an analogic and digital key. In this sense, the students were also asked to choose a work by Gehry and to prepare a short report to be presented to their colleagues through the support of two or three image slides, one of which was a drawing. The Danziger House, 700 I Melrose Avenue, was chosen for its stereometry and 'apparent' simplicity (fig. 3). Designed over two years, after a long trip to Europe, the house expresses the formal negotiation between some European experiences and the Californian tradition. The house is at the head lot of a row of buildings and is exposed on three sides. It is made up of two shifted, accosted boxes, which respectively house the residential areas and the production zone requested by the client, an artist photographer. Above them, two cubic skylights bring natural light into the atelier and the main bedroom. While the studio has an

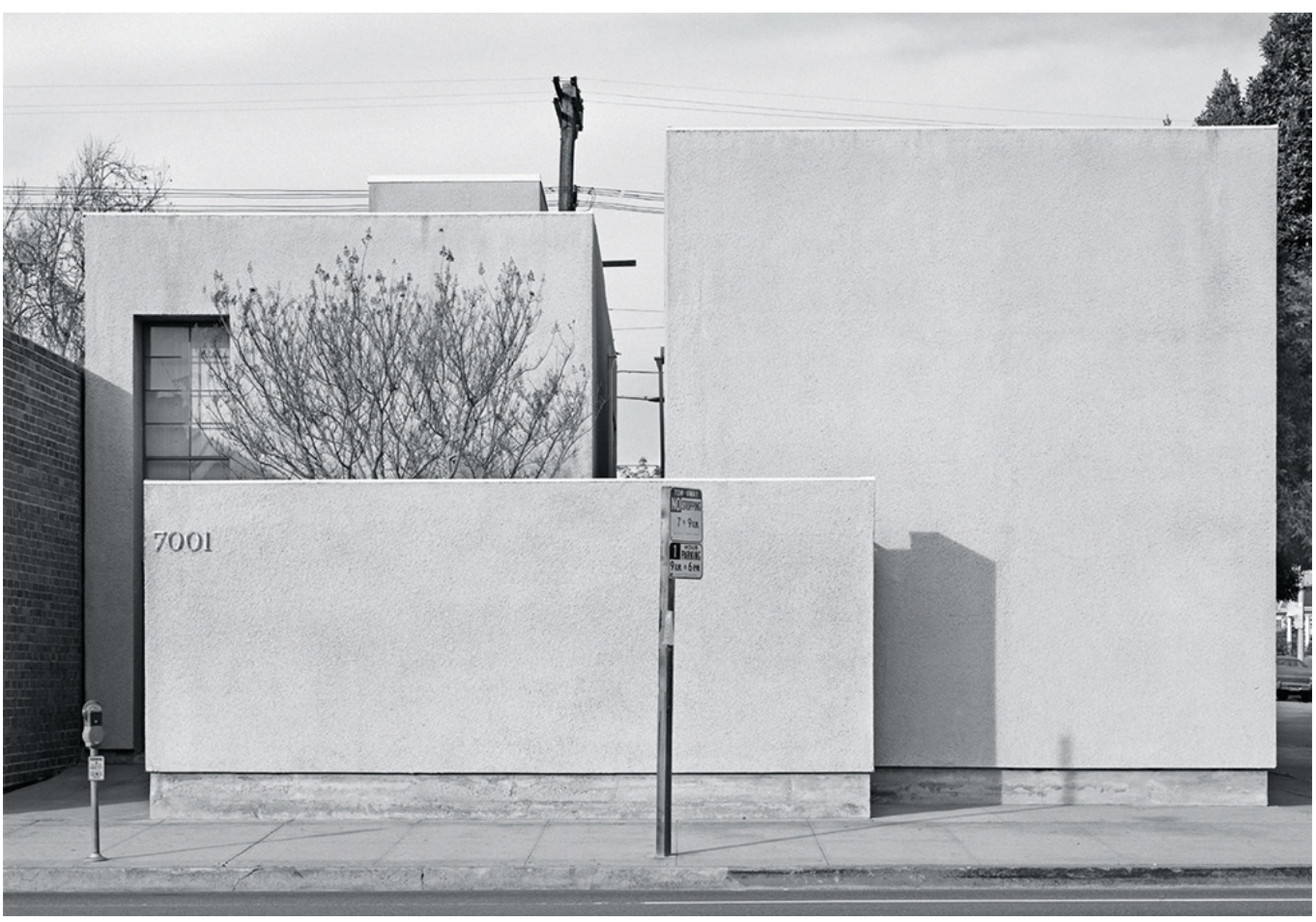


independent entrance, the residential block appears to be completely closed to the outside. Besides the large garage door, a small, wooden gate is the only visible entrance (fig. 4). Quite informally, it leads to a secret garden protected from the main street, Melrose Avenue, by a tall wall that turns sharply before touching the second box. Here, a large glass-door leads into the residential volume, featuring a double-height living room whit a kitchen below a sort of internal balcony. Behind the kitchen, there is a staircase leading up to the bedrooms and closing the private garage. A door leads from the kitchen to the full-height artist's study. It contains the lower box dedicated to the darkroom and large windows open to the north and east.

The graphic and iconographic documentation on the house [Cohen 2018], which was limited by the libraries lock-down, was enriched by the exploration of the site through Google-maps and Google-street view. As over the years the following owners have modified both the external form of the house and the organization of interiors, the students were asked to restore its original state in their drawings.

First of all, the students were asked to apply the notions of Descriptive Geometry acquired in the lessons in order to draw a roof plan and an elevation with shadows (fig. 5), a perspective view with the overturning procedure (fig. 6), an external axonometric view with shadows, and a sectioned or exploded axonometric view (fig. 7). Added to this, students have conjectured a route from outside to inside, fixed some points of view on it and sketched perspective views from those points, sometimes in watercolours (fig. 8). In this sense, the rigorously Cartesian boxes and the double-height interiors offered students an opportunity for a 'gentle' and 'mediated' transition from the Platonic solids of geometry exercises to the peculiarities of architectural drawing.

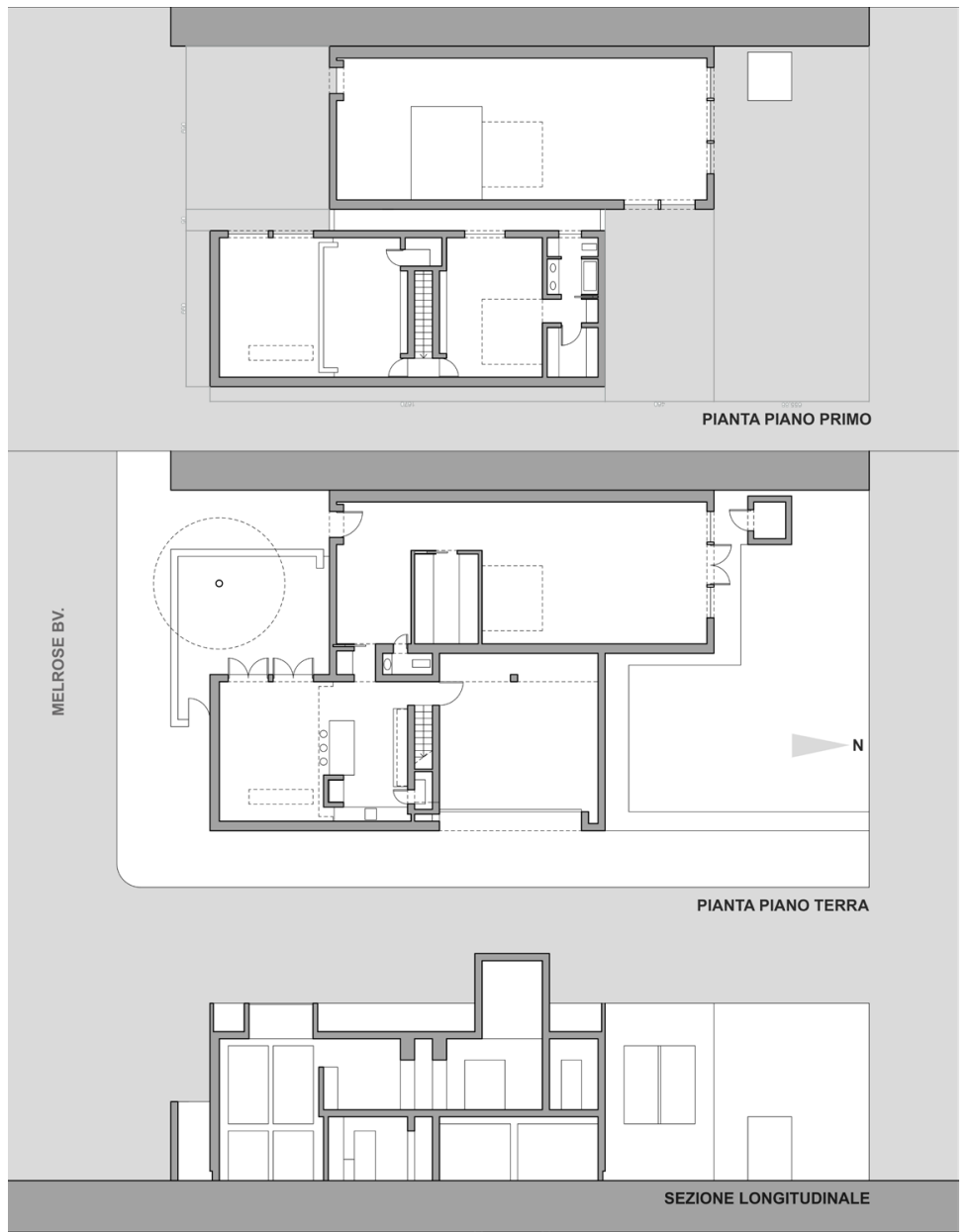


Fig. 4. F. Gehry, Danziger House, 1964-1965.

Digital collage elevation

(graphic elaboration by F. Colonnese).

Fig. 5. F. Gehry, Danzige House, 1964-1965. Roo plan and elevation with shadows in 1:50 scale

(graphic elaboration by

.Perna).

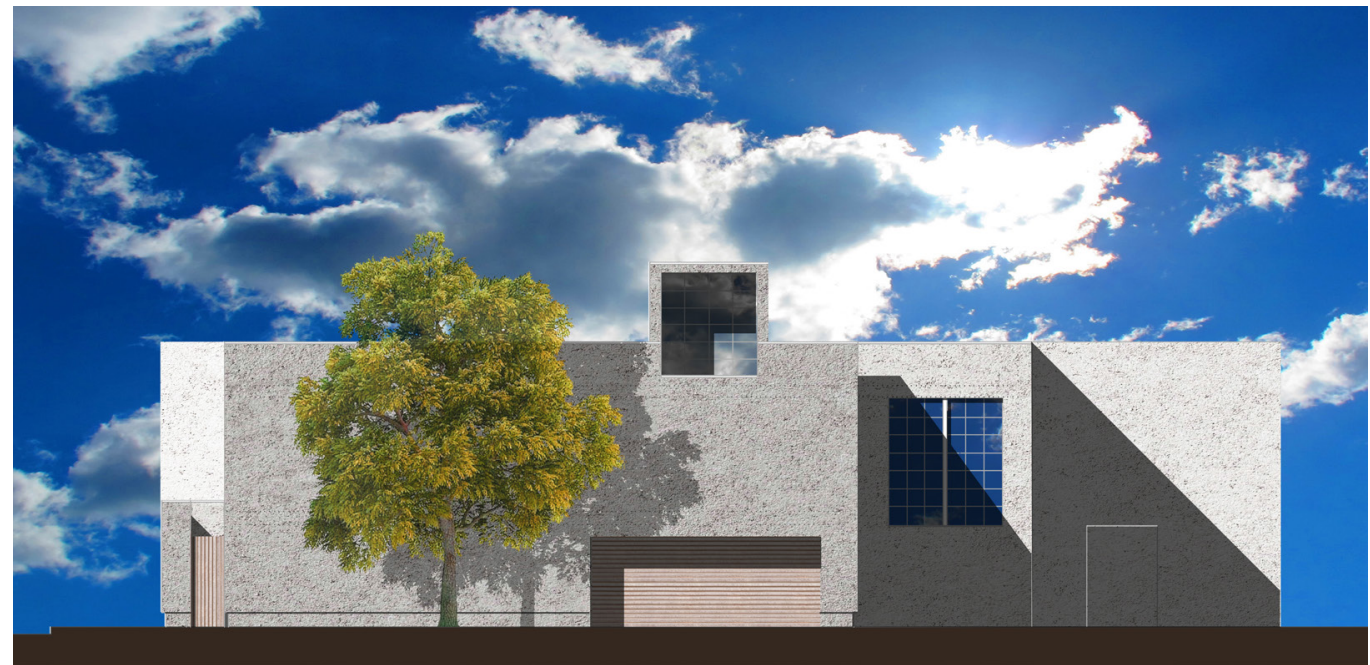

Two more panels were required as a digital application of architectural drawing. The former had to show the orthogonal projections of the house, partly provided by the course, partly produced by the students themselves, adding a graphic scale of reduction, texts, section lines and other conventional marks. The latter was dedicated to the views after the digital solid model constructed collegially during the Laboratory and represented in ways ranging from wireframe to rendering with materials and shadows (figs. 9-II).

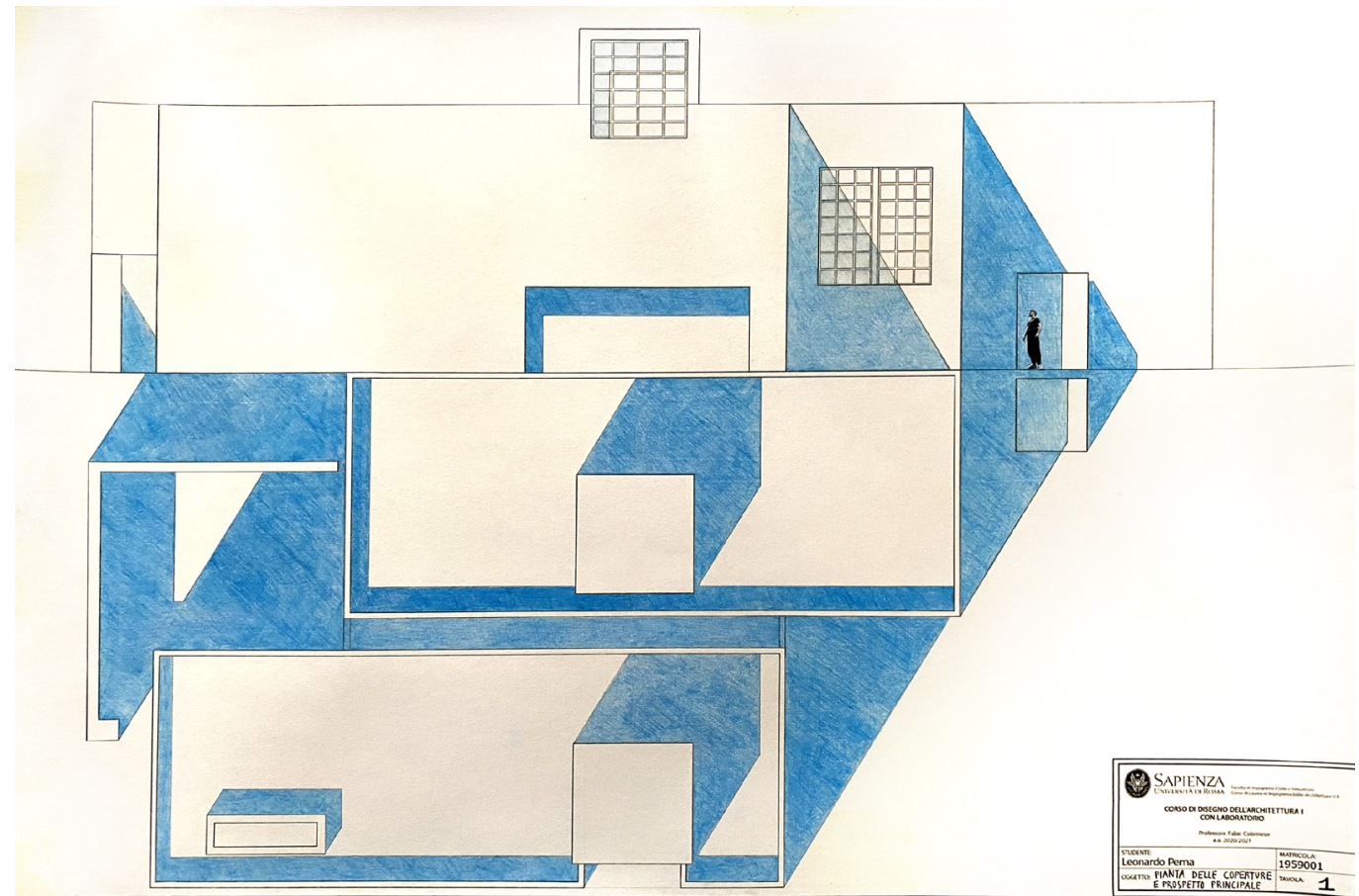

\section{Adjustments and reactions}

When teaching and exercises are held in presence, freshmen, after an initial orientation period, begin to relate to each other. They tend to organize themselves in small groups, to develop a mutual support, to share information and tricks, to emulate the good-practises and to grow their self-confidence. The maturation of the so-called soft skills is accompanied 
Fig. 6. F. Gehry, Danziger House, 1964-1965.

Perspective view with the overturning procedure (drawing L. Perna)

Fig. 7. F. Gehry, Danziger House, 1964- 1965.

1.100 scale (craphic

elaboration by A. Cricenti)
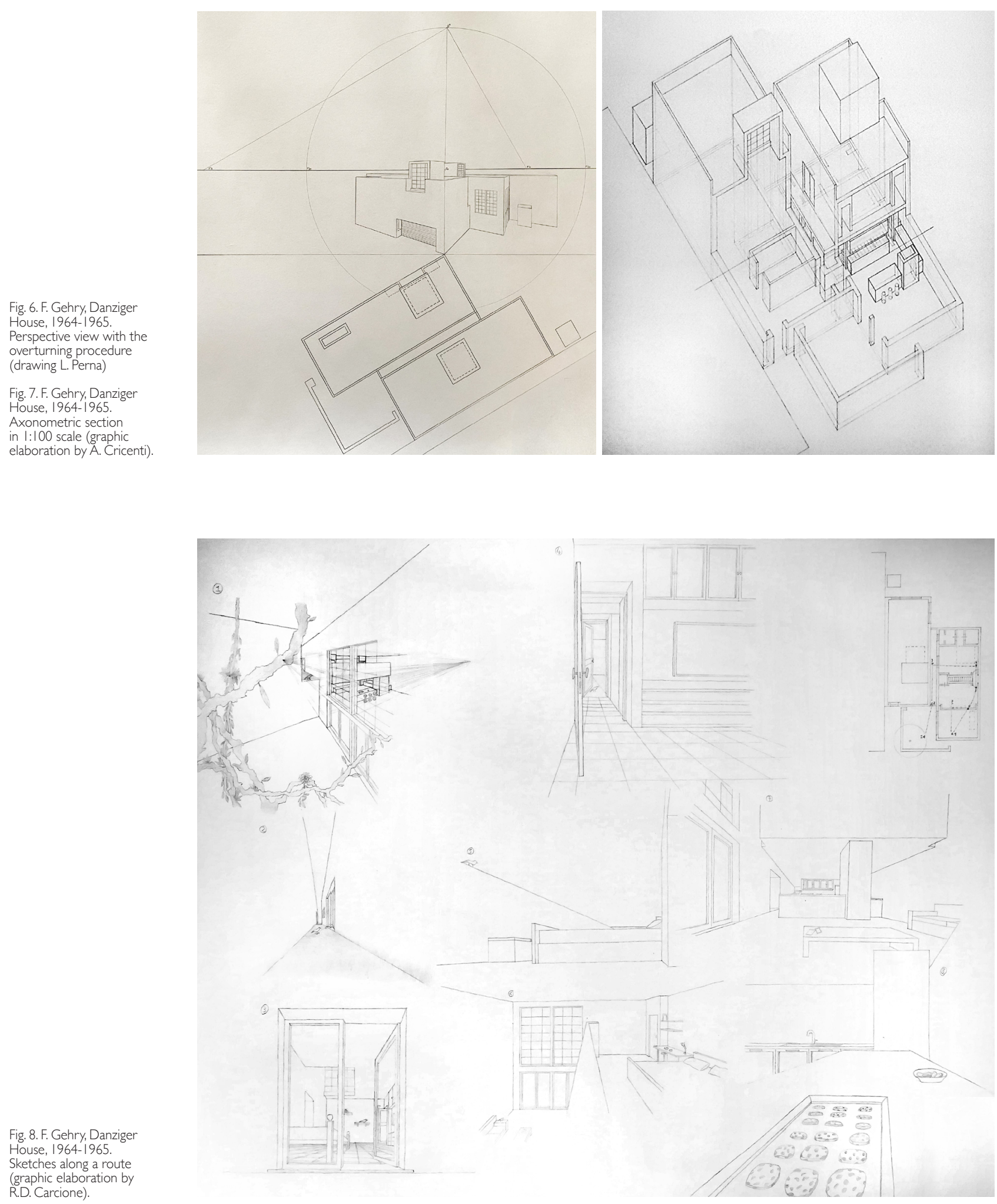

FIg. 8. F. Gehry, Danzige Sketches along a route Sketches along a route (graphic elaboration by
R.D. Carcione). 
by a series of behaviours that quickly transform a series of individuals into a class endowed with a sort of collective intelligence. Teaching in the socially distanced classroom, with half or more students attending from home, also has the contraindication of discouraging these behaviours and keeping the relationship between teacher and student on the level of individuality. To overcome this limitation, in addition to institutional platforms such as E-learning, some useful expedients have been put in place.

The collegial correction, albeit anonymous, of the exercises of Descriptive Geometry is one of these expedients. Another is the aforementioned public presentation of Gehry's works. In the sheet dedicated to the sketches of the house, students were suggested to think of particular routes and subjects, introducing a sort of 'role-play game' narration able to engage their imagination.

In some cases, small study groups spontaneously formed and worked home albeit keeping the social distance, but students were also encouraged to share their homework time through apps, such as Discord, that allow them to chat, share images and videos, and listen to music together while drawing. In this sense, teachers promoted this course as non-competitive work environment but rather open to error, experimentation and sharing.

Social distancing also discourages a direct emulation of the teacher, who is not allowed to sitting down near the students and drawing together with them, on their own sheets. To fight this situation, we limited the use of the traditional PowerPoint slide presentations. We constantly draw live, both explaining the methods of representation and exploring Gehry's Danziger House. In particular, we used a graphic tablet with Adobe Photoshop or Apple Concept or the large digital blackboard in the classroom, which is equipped with software for digital painting (fig. 12). Similarly, the exercises were corrected with digital software over screenshots. To facilitate this process, students were asked to draw with soft pencils to rend

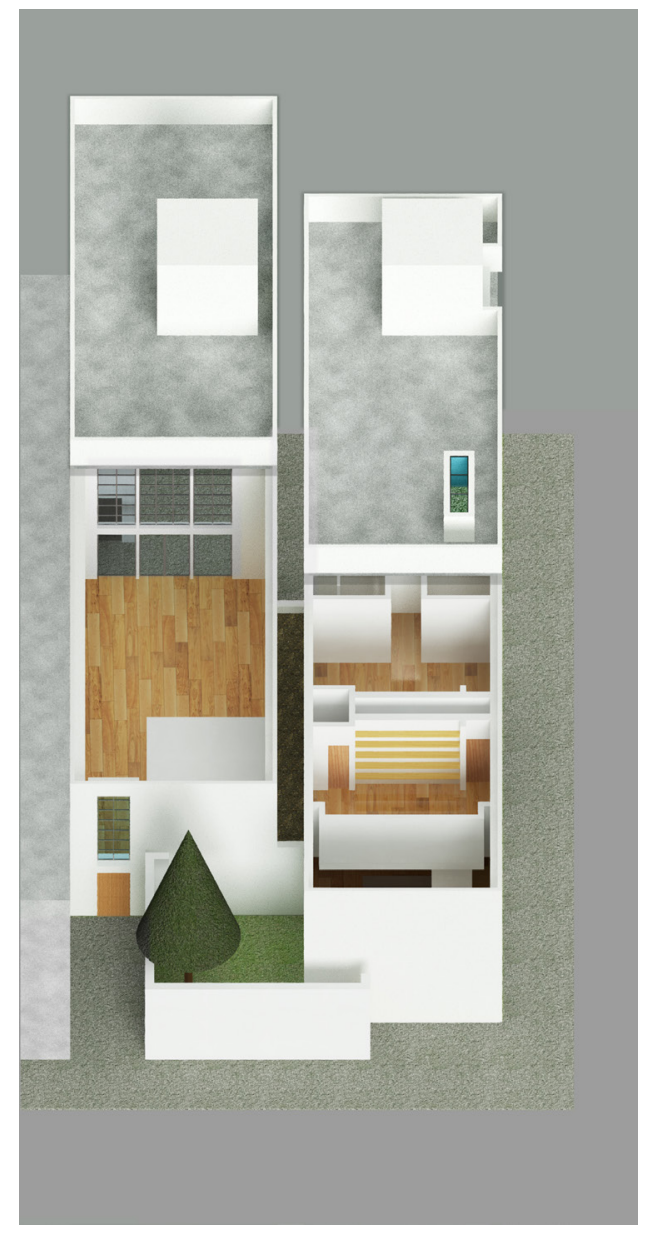




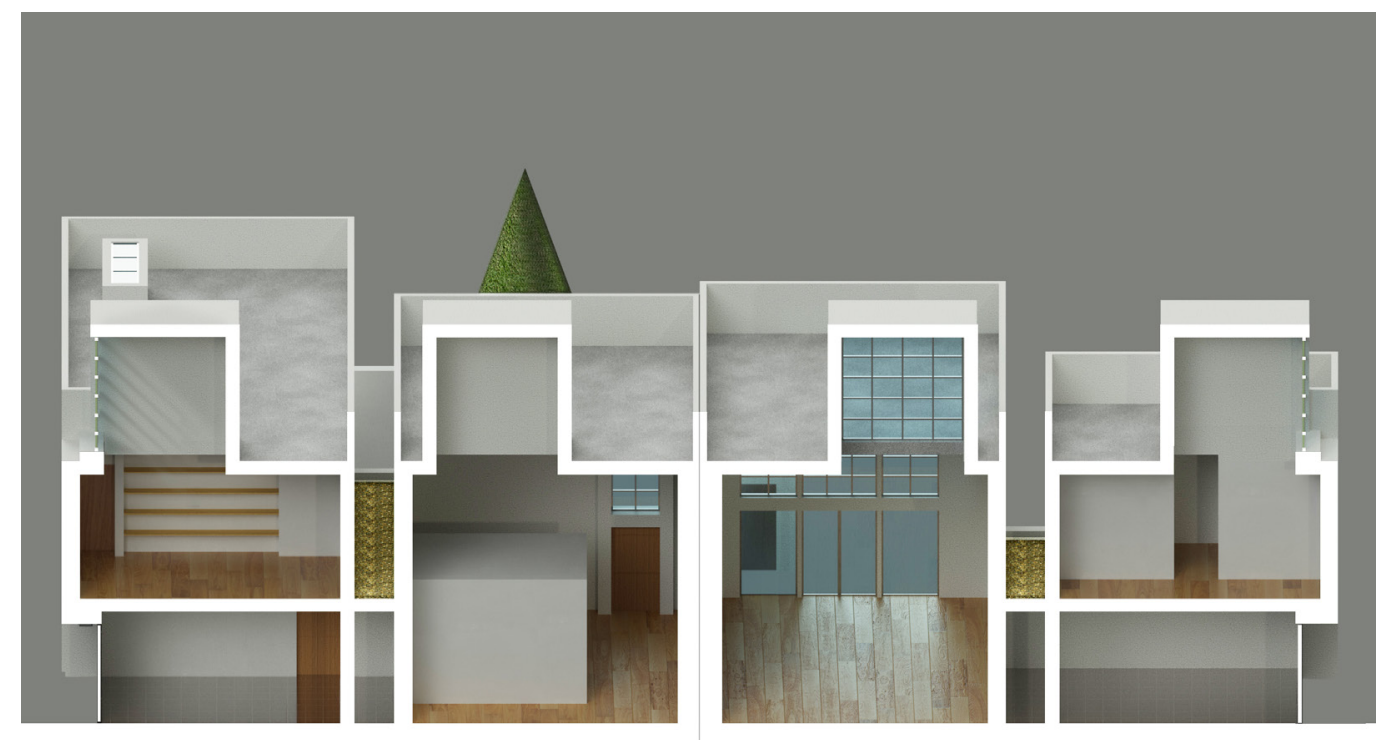

their drawing more visible and were provided with basic notions of Photoshop in order to optimize the digital pictures of their graphical works.

The students apparently reacted with an increasing and active presence to the course. While at the beginning only six or seven of them came to faculty, at the end of November, 28 of them, almost half of registered students, were present in the classroom. Despite the scheduled turns, some students asked to be invited almost always while others preferred to stay home for the whole course.

The students were accompanied to the exam both through some collegial reviews, always at a distance, and by question-and-answer emails. In the impossibility of carrying out written exams in a conventional way, the notions of geometry were verified through a series of small exercises to be performed and showed through the smartphone camera, while the Laboratory drawings were presented through photographs.

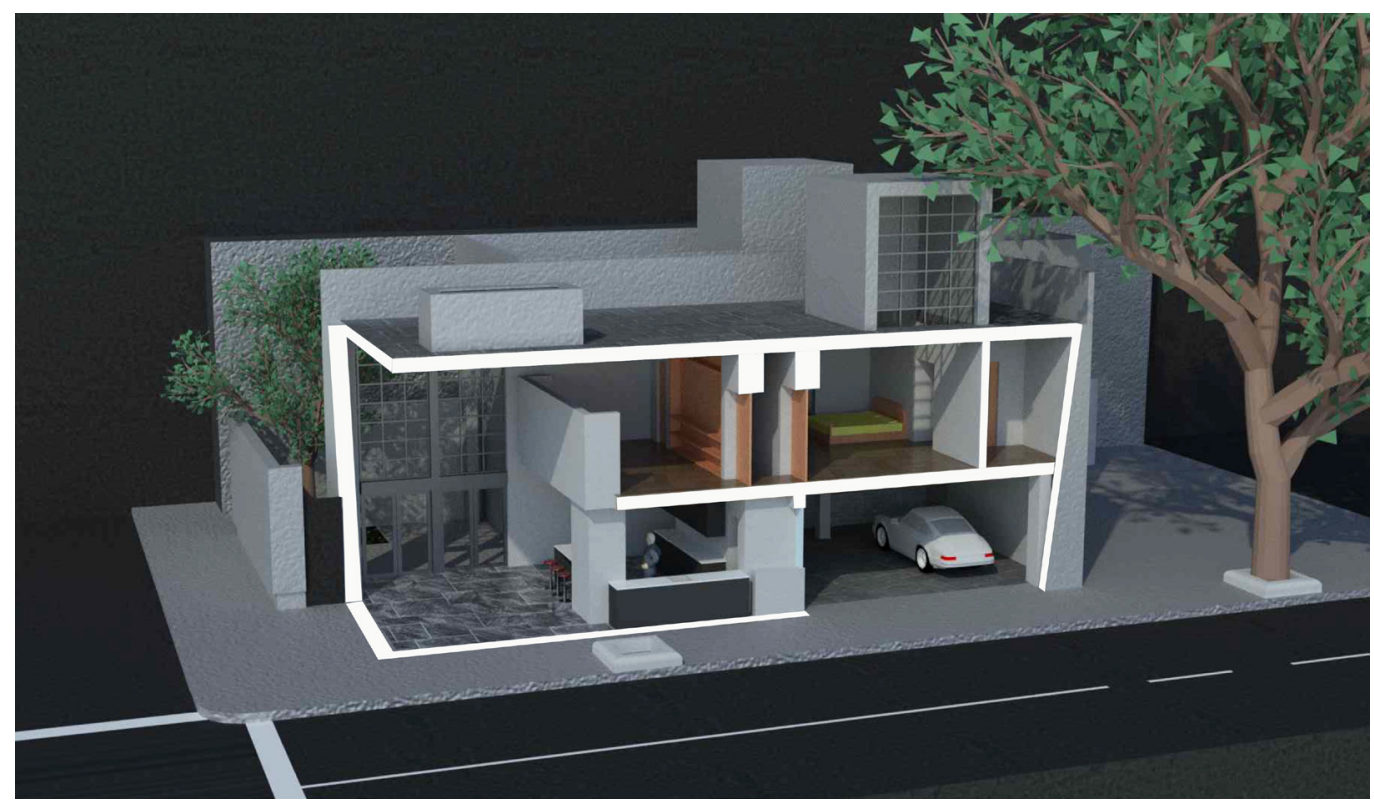




\section{Conclusions}

The early results of the critical review of the program and the experimentation of different methods and topics due to the pandemic and the six-month period of the Architectural Design course can be read in the students' exams. In February 2021, 54 exams of 67 registered students were carried out, about $80 \%$ of the total. This result makes it possible to judge on the effectiveness and limits of teaching architectural drawing at distance and, at the same time, the effects of the compression of course duration. While the number of exams can be considered a quantitative good result, the general quality of the students' work shows an evident decline. In particular, a number of them, especially the theory of shadow's applications, demonstrate of the students' difficulties in seeing with their mind in three dimensions. Despite the program had been partially resized, the time the students need to assimilate such complex spatial concepts cannot be compressed. Developing the ability to mentally explore three-dimensional problems may require months and a lot of exercises and it seems to be incompatible with an October-to-January course. At the same time, some of the students have missed the last revisions and the opportunity to refine and perfect their works.

This early judgment is also to be pondered with the particular conditions of the distance teaching of course. The students themselves stressed that, despite the difficulties in getting to university, the classroom offers opportunities for concentration and application that are by far higher than those they can have at home. Nevertheless, attendance in the classroom only partially constitutes an approval rating, since it was conditioned by external factors such as movement policy changes, a raising number of infections and even the absence of other teachers in the afternoon, which forced students to get back home in a few minutes and to attend the on-line lesson.

Another aspect is specifically a technical one. Implementing the hardware and software instrumentation as the course was proceeding forced the teachers and students to constant upgrading. The technical difficulties related to the efficiency of hardware and software were

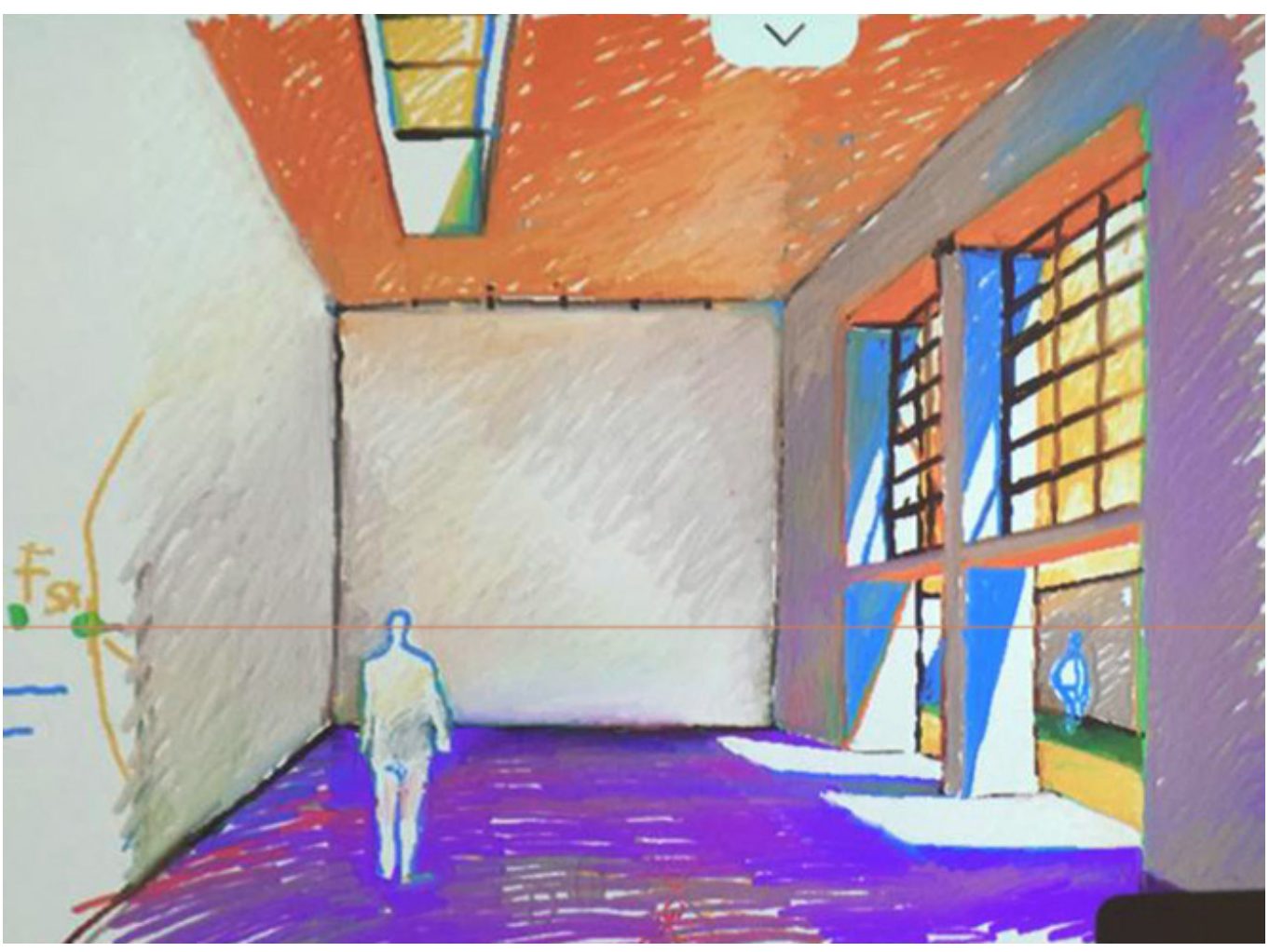


overcome only by the constant commitment and creativity of the teachers and the patience and participation of the students. This dynamic led to consider that the conditions imposed by the pandemic seem to have promoted an exceptional and favourable situation. In many cases, the general "hostile" situation favoured an exceptional atmosphere of participation, interaction and solidarity between teachers and students, "all in the same boat", which is worth to reflect and experiment upon in the next future.

\section{Acknowledgements}

We wish to thank the students of the course, and in particular Renato Danilo Carcione, Alessandra Cricenti and Leonardo Perna, for their active partecipation.

\section{References}

Cohen J.L. (20 18). Danziger Studio and Residence, Los Angeles, 1964- 1965. In Domus, n. I020, pp. 20-30.

Authors
Laura Carnevali, Sapienza Università di Roma, laura.carnevali@uniromal.it

Fabio Colonnese, Sapienza Università di Roma, fabio.colonnese@uniromal.it

To cite this chapter: Carnevali Laura, Colonnese Fabio (202I). Insegnare il disegno di architettura tra pandemia e semestralizzazione/Teaching architecture drawing between pandemic and semi-annualization. In Arena A., Arena M., Mediati D., Raffa P. (a cura di). Connettere. Un disegno per annodare e tessere. Linguaggi Distanze Tecnologie. Atti del $42^{\circ}$ Convegno Internazionale dei Docenti delle Discipline della Rappresentazione/Connecting. Drawing for weaving relationship. Languages Distances Technologies. Proceedings of the $42^{\text {th }}$ International Conference of Representation Disciplines Teachers. Milano: FrancoAngeli, pp. | 45 | - | 470. 